\title{
PERUBAHAN HISTOPATOLOGI JARINGAN KULIT IKAN KOMET (Carassius auratus auratus) AKIBAT INFESTASI Argulus japonicus
}

\author{
Histopathological change of comet fish (Carassius auratus auratus) skin tissues caused \\ Argulus japonicus
}

\author{
P Renita Efa Ratna Sari ${ }^{1}$, Wahju Tjahjaningsih ${ }^{2}$, and Kismiyati ${ }^{3}$ \\ ${ }^{1}$ Program Studi Budidaya Perairan, Fakultas Perikanan dan Kelautan, Universitas Airlangga, Surabaya \\ ${ }^{2}$ Departemen Kelautan, Fakultas Perikanan dan Kelautan, Universitas Airlangga, Surabaya \\ ${ }^{3}$ Departemen Manajemen Kesehatan Ikan dan Budidaya Perairan, Fakultas Perikanan dan Kelautan, Universitas \\ Airlangga, Surabaya \\ *renita-e-r-09@fpk.unair.ac.id
}

\begin{abstract}
Abstrak
Ektoparasit merupakan salah satu penyebab menurunnya nilai jual komoditas ikan hias di Indonesia. Infestasi tingkat akut $A$. japonicus dapat mengakibatkan kematian dan kerugian ekonomi bagi pembudidaya. Penetrasi stylet ektoparasit Argulus dapat menyebabkan kerusakan yang cukup besar dengan memecah konsistensi jaringan dan dapat menimbulkan iritasi pada kulit ikan. Tujuan dari penelitian ini adalah untuk dapat mengetahui perubahan atau kelainan pada tingkat jaringan yang disebabkan oleh ektoparasit $A$. japonicus pada jaringan kulit ikan komet. Penelitian ini dilaksanakan pada bulan September-Oktober 2013 di Laboratorium Pendidikan Fakultas Perikanan dan Kelautan dan Laboratorium Parasitologi Fakultas Kedokteran Hewan Universitas Airlangga. Metode yang digunakan dalam penelitian ini adalah metode eksperimental. Variabel yang diamati dalam penelitian ini adalah perubahan patologi anatomi dan perubahan histopatologi jaringan kulit ikan komet akibat infestasi A. japonicus. Skoring dilakukan untuk menentukan derajat kerusakan histopatologi jaringan kulit ikan komet. Hasil penelitian menunjukkan bahwa infestasi A. japonicus mengakibatkan perubahan hemoragi, erosi epitel epidermis, infiltrasi sel radang, kongesti, dan ballooning degeneration pada jaringan kulit ikan komet. Derajat infestasi ektoparasit $A$. japonicus berbanding lurus dengan tingkat kerusakan jaringan kulit ikan komet. Jenis kerusakan jaringan tidak menunjukkan hubungan yang linear dengan derajat infestasi A. japonicus. Diharapkan dilakukan penelitian lebih lanjut tentang kemungkinan terjadinya infeksi sekunder akibat infestasi A. japonicus pada ikan. Langkah pencegahan dan pengobatan yang sesuai untuk menjaga kesehatan ikan hias secara umum agar terlihat tetap mempunyai nilai estetika.
\end{abstract}

Kata kunci: Carassius auratus auratus, Argulus japonicus, histopatologi

\section{Abstract}

Acute infestation of $A$. japonicus can give occasion death and economic loss to farmers. Stylet penetration of ectoparasites $A$. japonicus caused considerable damage by breaking consistency of fish tissue and skin irritation. The purpose of this research was ascertain the level of comet fish skin tissues changes or abnormalities caused by ectoparasites A. japonicus. This research was conducted in September until October 2013 at the Faculty of Fisheries and Marine's Laboratory and Parasitology Laboratory of the Veterinary Medicine Faculty, Airlangga University. The variables observed in this study is the anatomic pathology and histopathological changes in the skin tissue of fish comet due to A. japonicus infestation. Scoring is done to determine the level of comet fish histopathology skin tissues damage. The results showed that the infestation of $A$. japonicus provide an overview histopathological changes inflammation, epidermis erotion, congestion, ballooning degeneration, and haemorrhage in comet fish skin tissues. Infestation level of ectoparasites $A$. japonicus is directly proportional with the level of comet fish tissue damages. Type of tissue damage does not have linear relationship with the level of $A$. japonicus infestation. Hopefully do the further research on the possibility of secondary infection due to A. japonicus infestations. Prevention and treatment measures appropriate to maintain the general health of ornamental fish to make it have aesthetic value.

Keywords: Carassius auratus auratus, Argulus japonicus, histopathology

\section{PENDAHULUAN}

Argulus japonicus merupakan agen penyebab penyakit argulosis terutama pada ikan air tawar (Walker et al., 2011). Ektoparasit $A$. japonicus dapat menyebabkan mortalitas tinggi yang bersifat akut, 
yaitu kematian yang terjadi tanpa menunjukkan gejala terlebih dahulu. Infestasi ektoparasit juga dapat menimbulkan kerugian non lethal, yaitu pertumbuhan yang lambat, penurunan efisiensi pencernaan, dan faktor predisposisi bagi infeksi jamur, bakteri dan virus. Selain itu dapat mempengaruhi tingkah laku ikan dan sensitivitas terhadap stresor, serta menurunkan nilai jual ikan (Scholz, 1999).

Penetrasi stylet ektoparasit Argulus dapat menyebabkan kerusakan yang cukup besar dengan memecah konsistensi jaringan dan dapat menimbulkan iritasi pada kulit ikan. Tingkat kerusakan kulit ikan akibat Argulus dapat dilihat secara detail melalui pengamatan pada tingkat jaringan. (Camargo and Martinez, 2007).

\section{METODOLOGI}

\section{Waktu dan Tempat}

Penelitian dilaksanakan selama 30 hari mulai bulan September sampai Oktober 2013. Pemeliharaan ikan terinfestasi $A$. japonicus dilakukan di Laboratorium Pendidikan Fakultas Perikanan dan Kelautan Universitas Airlangga. Pemeriksaan gambaran histopatologi jaringan kulit ikan komet akibat infestasi ektoparasit $A$. japonicus dilakukan di Laboratorium Patologi Veteriner Fakultas Kedokteran Hewan Universitas Airlangga.

\section{Peralatan Penelitian}

Peralatan yang digunakan dalam penelitian ini antara lain: 20 akuarium berukuran $(25 \times 15 \times 15) \mathrm{cm}^{3}$ dengan kapasitas volume lima liter, aerator, selang penyipon, seser, $\mathrm{pH}$ paper, termometer, DO meter, test kit, Beaker glass, alat sectio (gunting, pinset, dan skalpel), mikrotom, tissue casette, object glass, mikroskop cahaya, mikroskop stereo, pot plastik tempat fiksasi sampel, cover glass, hot plate, cetakan besi (base mold), tissue processor, dan kaca pembesar.

\section{Bahan Penelitian}

Bahan yang digunakan dalam penelitian ini antara lain: kulit dari ikan komet (Carassius auratus auratus), buffer netral formalin (BNF) 10\%, xylol, alkohol $70 \%$, alkohol $80 \%$, alkohol $90 \%$ dan alkohol absolut 96\%, parafin, pewarna Haematoxillin Eosin (HE).

\section{Metode Penelitian \\ Rancangan Penelitian}

Penelitian ini menggunakan metode eksperimental untuk mengetahui perubahan histopatologi jaringan kulit ikan komet (Carassius auratus auratus) akibat infestas $A$. japonicus. Rancangan percobaan yang menggunakan analisis Kruskal Wallis untuk mengetahui pengaruh derajat infestasi dengan kerusakan jaringan kulit ikan komet. Hasil data hubungan derajat infestasi dengan tingkat kerusakan patologi anatomi dibahas menggunakan analisis regresi dan korelasi.

\section{Prosedur Kerja \\ Pengambilan Sampel}

Ikan komet didapatkan dari pasar ikan hias Gunungsari Surabaya. Ikan komet yang digunakan dalam penelitian ini adalah ikan yang sehat, dan mempunyai ukuran seragam 7-10 cm. Menurut Isyagi et al (2009) ciri ikan yang sehat adalah memiliki bentuk dan fungsi tubuh yang normal, bersifat aktif dalam mengambil makan, dan tidak menunjukkan gejala abnormal akibat pengaruh stres atau penyakit.

Ektoparasit A. japonicus diperoleh dari ikan koi (Cyprinus carpio) di Desa Penataran Kabupaten Blitar. Ikan dimasukkan ke dalam kantong plastik dengan perbandingan oksigen dan air 1 : 3, kemudian dimasukkan ke dalam kotak styrofoam untuk menghindari goncangan berlebih selama perjalanan.

\section{Persiapan Media Pemeliharaan}

Perlakuan terdiri dari empat perlakuan dan lima ulangan. Setiap perlakuan menggunakan satu akuarium dengan padat tebar satu ekor/akuarium. Ikan dipuasakan terlebih dahulu selama 24 jam dengan tujuan untuk menghilangkan pengaruh sisa pakan dalam tubuh ikan.

Diterima/submitted:4 Januari 2014 Disetujui/accepted:24 Januari 2014 
Media pemeliharaan berupa air tawar. Air tersebut ditempatkan di dalam akuarium berukuran $(20 \times 10 \times 10) \mathrm{cm}^{3}$ sebanyak empat liter/akuarium. Kualitas air media pemeliharaan dijaga agar kondisinya tetap baik dengan melakukan penyiponan kotoran sisa pakan dan metabolisme dalam akuarium setiap hari.

Penyiponan sekaligus mengganti air sebanyak 50\% dari air sebelumnya. Air baru yang ditambahkan berasal dari bak tandon. Air tandon berasal dari sumur. Pengukuran dan pencatatan kualitas air dilakukan setiap hari. Pengukuran kualitas air meliputi $\mathrm{pH}$ dengan refraktometer, suhu dengan termometer, dan kelarutan oksigen dengan dissolved oxygen meter.

\section{Pelaksanaan Penelitian}

Penentuan Derajat Infestasi $\boldsymbol{A}$. japonicus

Identifikasi dilakukan secara mikroskopis terhadap A. japonicus berdasarkan kunci identifikasi Seng (1986) dan Stammer (1959) dengan perbesaran 400x. Berdasarkan hasil identifikasi menunjukkan bahwa $A$. japonicus memiliki ciri tubuh pipih dorso ventral yang terbagi menjadi tiga bagian, yaitu cephal, thorax dan abdomen. Tubuh A. japonicus memiliki panjang antara $4 \mathrm{~mm}-6 \mathrm{~mm}$. Argulus japonicus memiliki carapace mulai bagian dorsal sampai pangkal abdomen, respiratory area kecil pada bagian anterior dan bagian posterior yang hampir memenuhi area respirasi. Ciri spesifik yang lain A. japonicus adalah mempunyai 6-7 supporting rods, serta terdapat tiga tonjolan pada maxilla.

Infestasi buatan A. japonicus pada ikan komet dibagi dalam tiga kategori, yaitu infestasi ringan untuk lima ekor $A$. japonicus, infestasi sedang untuk 10 ekor $A$. japonicus, dan infestasi berat untuk 15 ekor A. japonicas. Infestasi buatan dilakukan dengan cara menempatkan $A$. japonicus dan ikan komet yang sehat dalam beaker glass berisi air $400 \mathrm{ml}$ selama kurang lebih 15 menit. Ikan yang sudah terinfestasi Argulus dimasukkan kembali ke dalam akuarium perlakuan.

\section{Pengamatan Perubahan Patologi Anatomi Ikan Komet}

Pengamatan dan analisis perubahan patologi anatomi dilakukan dengan skoring berdasarkan luasan kerusakan pada permukaan sisi ikan dari bagian kepala sampai sirip caudal. Dasar skoring yang digunakan yaitu :

Nilai 0 : jika belum terjadi kerusakan pada kedua sisi ikan komet (belum terjadi perubahan patologi).

Nilai 1: jika terdapat bagian yang luka kurang dari atau sama dengan 25\% pada kedua sisi ikan komet.

Nilai 2: jika terdapat bagian yang luka lebih dari atau sama dengan 26-50\% pada kedua sisi ikan komet.

Nilai 3 : jika terdapat bagian luka lebih dari atau sama dengan $51-75 \%$ pada kedua sisi ikan komet.

Nilai 4 : jika terdapat bagian yang luka lebih dari atau sama dengan $76 \%$ pada kedua sisi ikan komet.

\section{Pemeriksaan Histopatologi Jaringan Kulit Ikan Komet}

Pemeliharaan ikan dalam akuarium dilakukan selama seminggu. Skoring dilakukan pada hari ke tujuh untuk menentukan derajat kerusakan jaringan pada kulit ikan secara histopatologi. Dasar skoring yang digunakan yaitu :

Nilai 0 : jika belum terjadi kerusakan pada satu lapang pandang (belum terjadi perubahan patologi).

Nilai 1 : jika terdapat perubahan histopatologi kurang dari atau sama dengan $25 \%$ pada satu lapang pandang, merupakan tingkat kerusakan ringan

Nilai 2 : jika terdapat perubahan histopatologi lebih dari atau sama dengan 26-50\% pada satu lapang pandang, merupakan tingkat kerusakan sedang.

Nilai 3 : jika terdapat perubahan histopatologi lebih dari atau sama dengan 51-75\% pada satu lapang pandang, merupakan tingkat kerusakan berat. 
Nilai $4:$ jika terdapat perubahan histopatologi lebih dari atau sama dengan $76 \%$ pada satu lapang pandang, merupakan tingkat kerusakan sangat berat

Pengamatan dan analisa gambaran histopatologi dilakukan pada hari terakhir dalam seminggu pemeliharaan. Perubahan gambaran histopatologi jaringan kulit ikan komet dicatat dan diamati untuk mengetahui tingkat kerusakan jaringan pada ikan komet.

\section{Parameter}

Parameter utama pada penelitian ini adalah perubahan histopatologi jaringan kulit ikan komet terinfestasi A. japonicus. Pengamatan perubahan histopatologi berdasarkan pada perubahan abnormalitas jaringan kulit yang dilihat secara mikroskopik. Pengamatan parameter utama dilakukan pada hari ketujuh.

Parameter penunjang pada penelitian adalah tingkat kerusakan patologi anatomi yang diamati pada hari ke tujuh dan pengukuran kualitas air meliputi suhu, $\mathrm{pH}$ dan oksigen terlarut yang diukur setiap hari selama penelitian.

\section{Analisis Data \\ Analisis statistik menggunakan Kruskal Wallis untuk mengetahui pengaruh perlakuan. Hasil data hubungan derajat infestasi dengan tingkat kerusakan patologi anatomi dibahas menggunakan analisis regresi dan korelasi. \\ HASIL DAN PEMBAHASAN \\ Hasil Penentuan Perubahan Patologi Anatomi Ikan Komet}

Ikan kontrol menunjukkan aktivitas berenang yang normal dan terlihat sehat sampai akhir penelitian. Perubahan patologi anatomi ikan komet sangat terlihat pada sirip caudal dan sirip ventral. Pendarahan ditandai dengan terdapatnya guratan berwarna merah pada sirip. Pendarahan juga ditemukan pada kulit. Pada akhir perlakuan, terlihat sisik ikan rontok dan warna kulit yang agak pucat. Beberapa ikan berenang tidak teratur, dan beberapa mati pada hari keenam perlakuan. Kerusakan patologi anatomi dapat dilihat pada Tabel 1. Hubungan derajat infestasi $A$. japonicus dan kerusakan patologi anatomi ikan komet Gambar 1.

Tabel 1. Kerusakan patologi anatomi ikan komet

\begin{tabular}{ccc}
\hline Derajat infestasi & Nilai rerata & Derajat kerusakan \\
\hline Kontrol & $0^{\mathrm{d}}$ & Normal \\
\hline Ringan $(5$ A. japonicus $)$ & $1^{\mathrm{c}}$ & Ringan \\
\hline Sedang $(10$ A. japonicus $)$ & $1,5^{\mathrm{b}}$ & Sedang \\
\hline Berat $(15$ A. japonicus $)$ & $2,5^{\mathrm{a}}$ & Berat \\
\hline
\end{tabular}

Keterangan: notasi a, b, c, dan d menunjukkan perbedaan yang signifikan( $\mathrm{p}<0,05)$

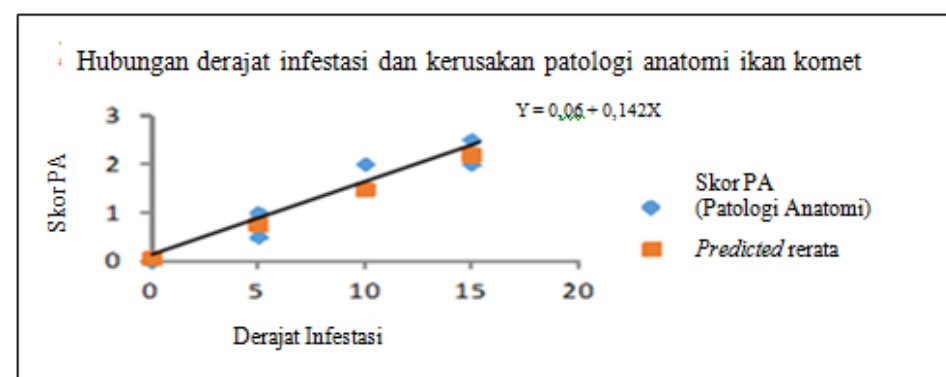

Gambar 1. Hubungan derajat infestasi A. japonicus dan kerusakan patologi anatomi ikan komet 


\section{Hasil Pemeriksaan Perubahan Histopatologi Ikan Komet}

Hasil pengamatan kerusakan histopatologi jaringan kulit ikan komet (Tabel 2) menunjukkan bahwa pada kulit ikan komet kontrol tidak terdapat perubahan histopato- logi. Perubahan histopatologi jaringan kulit ikan komet (Gambar 2) yang terinfestasi $A$. japonicus adalah infiltrasi sel radang (IR), hemoragi $(\mathrm{H})$, kongesti $(\mathrm{K})$, erosi epitel epidermis (EP), dan ballooning degeneration $(\mathrm{BD})$.

Tabel 2. Kerusakan histopatologi jaringan kulit ikan komet

\begin{tabular}{cccc}
\hline Derajat infestasi & Nilai rerata & $\begin{array}{c}\text { Derajat } \\
\text { kerusakan }\end{array}$ & $\begin{array}{c}\text { Perubahan } \\
\text { histopatologi }\end{array}$ \\
\hline Kontrol & $0^{\mathrm{d}}$ & Normal & Normal \\
\hline $\begin{array}{c}\text { Ringan } \\
(5 \text { A. japonicus })\end{array}$ & $1,2^{\mathrm{c}}$ & Ringan & $\begin{array}{c}\text { Infiltrasi sel } \\
\text { radang, erosi } \\
\text { epitel epidermis }\end{array}$ \\
\hline $\begin{array}{c}\text { Sedang } \\
(10 \text { A. japonicus })\end{array}$ & $2,2^{\mathrm{b}}$ & Sedang & $\begin{array}{c}\text { Infiltrasi sel } \\
\text { radang, } \\
\text { ballooning } \\
\text { degeneration }\end{array}$ \\
\hline $\begin{array}{c}\text { Berat } \\
(15 \text { A. japonicus })\end{array}$ & $3,8^{\mathrm{a}}$ & Berat & $\begin{array}{c}\text { Infiltrasi sel } \\
\text { radang, } \\
\text { hemoragi, } \\
\text { kongesti }\end{array}$ \\
\hline
\end{tabular}

Keterangan: notasi $a, b, c$, dan $d$ menunjukkan perbedaan yang signifikan $(p<0,05)$

Rerata skoring perubahan gambaran histopatologi jaringan mempunyai hubungan linear dengan perubahan patologi anatomi kulit ikan komet. Semakin banyak jumlah A. japonicus yang menginfestasi, rerata skoring pada perubahan patologi anatomi semakin tinggi. Hal ini menunjukkan bahwa semakin banyak jumlah parasit, maka semakin parah menimbulkan kerusakan patologis. Hal ini juga terjadi pada perubahan histopatologi jaringan secara mikroskopik.

Hubungan derajat infestasi dan kerusakan patologi anatomi ikan komet menunjukkan korelasi yang positif. Grafik persamaan $\mathrm{y}=0,06+0,142 \mathrm{x}$ menunjukkan bahwa semakin tinggi derajat infestasi $A$. japonicus, semakin tinggi skor patologi anatomi ikan komet. Nilai koefisien korelasi $(r=0,98)$ menunjukkan adanya pengaruh yang kuat antara derajat infestasi A. japonicus terhadap perubahan patologi anatomi. Hal ini juga dapat dilihat dari nilai rerata derajat infestasi berat $(2,5)$ yang memberikan dampak kerusakan patologi anatomi yang berbeda nyata $(p<0,05)$ dengan perlakuan kontrol (0), derajat infestasi ringan (1) dan derajat infestasi sedang $(1,5)$. Berdasarkan analisis tersebut dapat disimpulkan bahwa semakin tinggi derajat infestasi $A$. japonicus, semakin tinggi tingkat kerusakan patologi anatomi ikan komet yang ditimbulkan. Hal ini terlihat dari adanya pendarahan pada beberapa bagian kulit dan sirip. Pendarahan pada infestasi berat terlihat lebih jelas dan dominan dibandingkan dengan derajat infestasi sedang dan infestasi ringan. 
Journal of Aquaculture and Fish Health Vol. 3 No.1
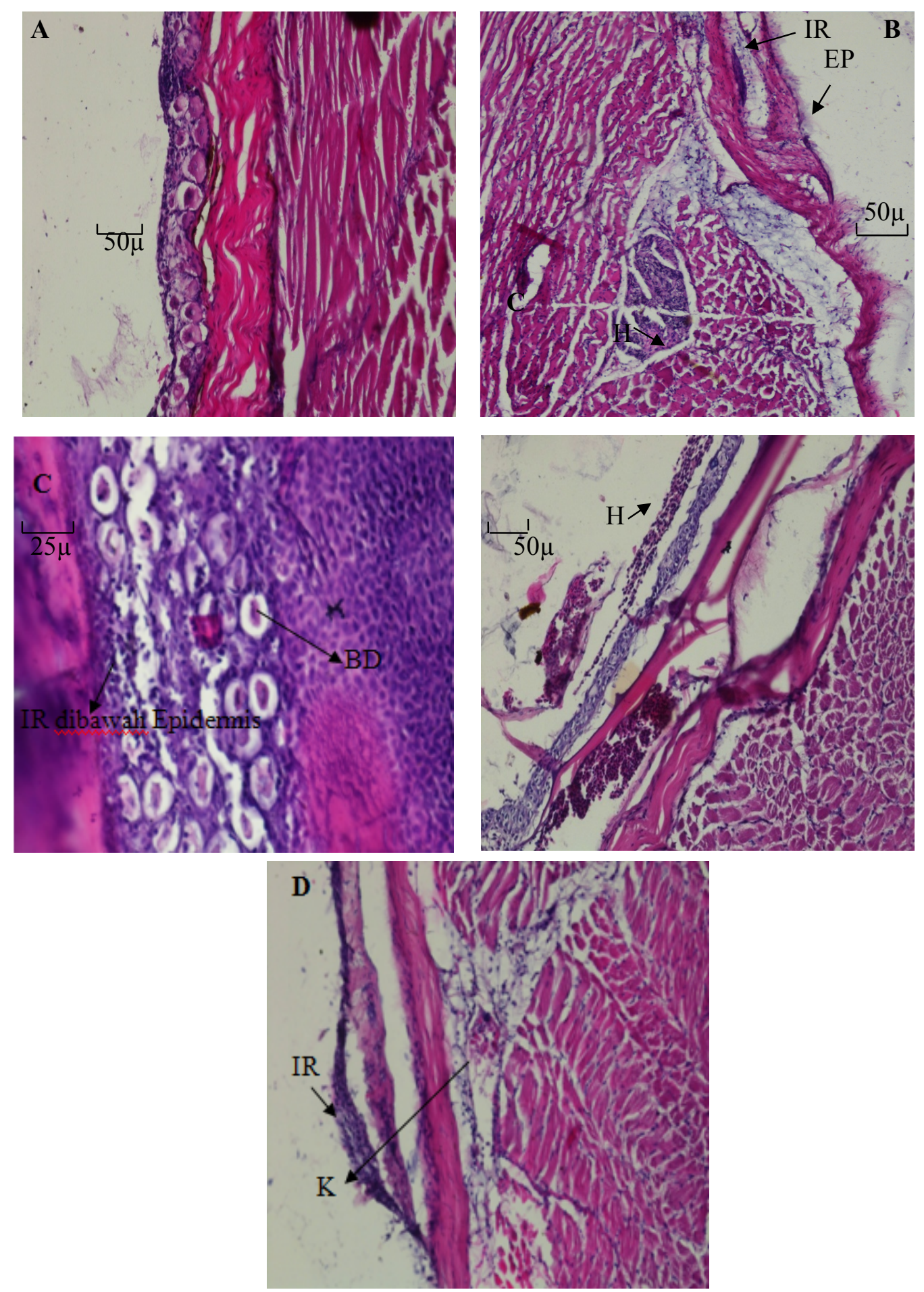

Gambar 2. Perubahan histopatologi jaringan kulit ikan komet (perbesaran 200x;400x)

Keterangan : (A) kontrol, (B) infestasi ringan, (C) infestasi sedang, (D) infestasi berat (IR) infiltrasi sel radang, $(\mathrm{H})$ hemoragi, $(\mathrm{K})$ kongesti, $(\mathrm{EP})$ erosi epitel epidermis, dan (BD) ballooning degeneration

Pendarahan pada ikan karena serangan $A$. japonicus disebabkan oleh iritasi dari bahaya mekanis hooks dan stylet (Steckler and Yanong, 2012). Bintik merah

Diterima/submitted:4 Januari 2014 Disetujui/accepted:24 Januari 2014 
pendarahan (petechiae) akibat A. japonicus diakibatkan oleh berbagai macam sebab, diantaranya adalah karena adanya toksin yang dikeluarkan oleh parasit pada saat terjadi infestasi. Toksin yang dikeluarkan oleh $A$. japonicus adalah berupa enzim antikoagulan yang berfungsi untuk mencegah terjadinya pembekuan darah (Ghazali dkk., 2012). Pendarahan dan kerusakan jaringan pada bagian luar kulit ikan yang terserang dapat mengakibatkan inflamasi atau infiltrasi sel radang diikuti dengan kerusakan jaringan lainnya (Notash, 2012).

Nilai rerata derajat infestasi berat $(3,8)$ menunjukkan dampak perubahan histopatologi jaringan kulit yang signifikan terhadap perlakuan kontrol (0), derajat infestasi ringan $(1,2)$ dan derajat infestasi sedang $(2,2)$. Hal ini juga dapat dilihat dari hasil uji Kruskal Wallis yang menunjukkan hasil yang signifikan $(p<0,05)$. Berdasarkan analisis tersebut dapat disimpulkan bahwa semakin tinggi derajat infestasi $A$. japonicus, semakin tinggi tingkat perubahan histopatologi jaringan kulit ikan komet yang ditimbulkan.

Berdasarkan hasil penelitian ini, tingkat kerusakan patologi anatomi dan perubahan histopatologi jaringan kulit ikan komet yang terjadi mengikuti derajat infestasi ektoparasit $A$. japonicus. Menurut Bandilla (2007) produksi mucus pada ikan berperan sebagai perlindungan terluar sehingga dapat mereduksi pengaruh berbahaya dari serangan parasit yang sifatnya ringan. Jumlah parasit yang lebih banyak dapat merusak mekanisme osmoregulasi dan pertahanan tubuh sehingga menimbulkan tingkat kerusakan kulit dan jaringan yang lebih tinggi. Menurut Walker (2008) kerusakan kulit dan jaringan yang terjadi berkaitan dengan efek mekanis stylet $A$. japonicus yang dapat menimbulkan luka pada kulit dan jaringan. Semakin banyak jumlah ektoparasit $A$. japonicus yang menempel, semakin tinggi kemungkinan tingkat kerusakan yang ditimbulkan dari $A$. japonicus sebagai agen biologis yang bersifat destruktif.
Jenis kerusakan jaringan yang terdeteksi diduga tidak mencerminkan hubungan yang linear dengan derajat infestasi ektoparasit $A$. japonicus. Jenis kerusakan jaringan yang berbeda tidak bisa dibandingkan diantara masing-masing derajat infestasi karena hanya bisa diukur dan dibandingkan dengan jenis kerusakan yang sama $^{\mathrm{a}}$.

Jenis kerusakan jaringan yang berbeda diduga berkaitan dengan perilaku $A$. japonicus. Taylor (2005) menyatakan bahwa $A$. japonicus cenderung bersifat temporer, menempel pada inang secara acak dan dapat berpindah dengan bebas pada tubuh ikan atau bahkan meninggalkannya.

Jenis kerusakan jaringan yang paling banyak dan ditemukan pada setiap tingkatan infestasi adalah infiltrasi sel radang. Underwood (1992) menyatakan bahwa infiltrasi sel radang pada tingkat akut ditandai dengan adanya peningkatan permeabilitas pembuluh darah, cairan, dan sel yang keluar dari pembuluh darah serta adanya netrofil pada jaringan yang mengalami radang.

Hasil pengamatan histopatologi menunjukkan kerusakan kongesti pada perlakuan infestasi berat. Banyaknya $A$. japonicus yang menempel pada derajat infestasi berat mengakibatkan kongesti semakin jelas terlihat pada tingkat kerusakan berat ini.Menurut Wiegertjes and Flik (2004) kongesti merupakan berlimpahnya darah dalam area pembuluh darah tertentu. Pembendungan darah biasanya terjadi pada pembuluh darah vena. Kongesti dapat menyebabkan hemoragi jika darah keluar dari pembuluh darah. Terjadinya kongesti disertai oleh peningkatan jumlah sel-sel granul eosinofil.

Hasil pengamatan sediaan histopatologi juga terdapat erosi epitel epidermis pada derajat infestasi ringan. Erosi epitel epidermis merupakan pengikisan lapisan epidermis yang diduga terjadi saat ektoparasit $A$. japonicus menempel pada kulit ikan komet. Sharma et al. (2012) menyatakan bahwa ektoparasit $A$. japonicus

Diterima/submitted:4 Januari 2014

Disetujui/accepted:24 Januari 2014 
memasukkan stylet ke dalam epidermis sampai lapisan jaringan dibawahnya. Hal ini berpotensi mengakibatkan kerusakan erosi jaringan epidermis karena penetrasi stylet menembus lapisan epidermis dengan cara menusuk sehingga mengakibatkan pengikisan epitel epidermis.

Berdasarkan hasil penelitian ini, kerusakan jaringan ballooning degeneration ditemukan pada perlakuan infestasi sedang. Battenay and Hargis (2006) menjelaskan bahwa ballooning degeneration ditandai dengan adanya pembengkakan sel pada lapisan epidermis yang terjadi karena edema intraseluler. Sel terlihat membesar dan didalamnya terdapat ruang kosong seperti ballon cells.

\section{Hasil Pemeriksaan Kualitas Air}

Hasil pemeriksaan kualitas air selama penelitian berada pada kisaran normal untuk pemeliharaan ikan komet, yaitu suhu $24-25^{\circ} \mathrm{C}, \mathrm{pH} 7-8$, dan DO 5-6 $\mathrm{mg} / \mathrm{l}$.

Kualitas air akuarium ikan komet pada penelitian ini menunjukkan bahwa kondisi air kolam dalam kondisi normal bagi ikan komet. Hasil pengukuran kualitas air di akuarium ikan koi menunjukkan suhu kolam adalah $\pm 25^{\circ} \mathrm{C}, \mathrm{pH}$ air $7-8$, dan oksigen terlarut (DO) 5-6 mg/l. Kondisi pemeliharaan ikan komet yang baik selama penelitian dapat meminimalkan pengaruh lain di luar pengaruh infestasi $A$. japonicus agar data dapat digunakan sebagai acuan untuk pengembangan ilmu pengetahuan.

\section{KESIMPULAN DAN SARAN Kesimpulan}

Berdasarkan hasil yang diperoleh kesimpulan pada penelitian ini adalah infestasi A. japonicus mengakibatkan hemoragi, erosi epitel epidermis, infiltrasi sel radang, kongesti, dan ballooning degeneration pada jaringan kulit ikan komet. Selain itu, derajat infestasi $A$. japonicus berbanding lurus dengan tingkat kerusakan jaringan kulit ikan komet. Jenis kerusakan jaringan tidak mencerminkan hubungan yang linear dengan derajat infestasi ektoparasit A. japonicus.

\section{Saran}

Diharapkan dilakukan penelitian lebih lanjut tentang tentang kemungkinan terjadinya infeksi sekunder yang ditimbulkan akibat infestasi $A$. japonicus pada ikan.

\section{DAFTAR PUSTAKA}

Bandilla, M. 2007. Transmission, Host and Mate Location in The Fish louse Argulus. Biological and Environmental Science. University of Jyvaskyla. Germany. pp. 10-13.

Bettenay, S. V. and A. M. Hargis. 2006. Veterinary Dermatopathology. Teton New Media. Press. New York. pp. 6566.

Camargo, M. M. P. and C. B. R. Martinez. 2007. Histopathology of gills, kidney and liver of a Neotropical fish caged in an urban stream. Neotropical Ichthyology, 5(3) : 327-336.

Ghazali, M., Kismiyati, G. Mahasri. 2012. Pemberian Perasan Buah Mengkudu (Morinda citrifolia) Untuk Pengendalian Argulus Pada Ikan Mas Komet (Carassius auratus auratus). Jurnal Ilmiah Perikanan dan Kelautan, 4 (1): 45-48.

Isyagi, N. A., K. L. Veverica., R. Asiimwe, and W. H. Daniels. 2009. Manual for the Commercial Pond Production of the African Catfish in Uganda, Feed and Feeding the Fish. Department of Fisheries and Allied Aquacultures. Auburn University Alabama, USA. pp.13-14.

Notash, S. 2012. Study on Prevalence of Argulus in Goldfishes of East Azerbaijan province of Iran. Annals of biological Research, 3 (7): 3444 3447.

Scholz, T. 1999. Parasite in Cultured and Feral Fish. Veterinary Parasitology. 84 : 317-335.

Seng, L. T. 1986. Two Ectoparasite Crustaceans Belonging To The Family Argulidae

Diterima/submitted:4 Januari 2014 Disetujui/accepted:24 Januari 2014 
(Crustacea:Branchiura) in Malaysian Freshwater Fishes. Malayan Nature Journal, 39 : 157-164.

Sharma, M., A. B. Shrivastav., Y. P. Sahni., and G. Pandey. 2012. Overview of The Treatment and Control of Common Fish Diseases. International Research Journal of Pharmacy, 3(7): 123-127.

Stackler, N., and R. P. E. Yanong. 2012. Argulus (Fish Louse) Infections in Fish. Fisheries and Aquatic Sciences Publications. University of Florida. Florida. pp. 1-4.

Stammer, J. 1959. Beitrage Zur Morphologie, Biologie Und Bekampfung Der Karpfenlause. Aus dem Zoologischen Institut der Universitat Erlangen, 19: 135-208.

Taylor, N. G. H. 2005. A Review of Argulus spp Occuring in United Kingdom Freshwaters (Science Reports). The Environment Agency Protecting and Improving The Environment in England and Wales. pp. 30.

Underwood, J C E. 1992. General and Systematic Pathology. Churchill Livingstone, New York. pp. 133136.

Walker, P. 2008. Argulus The Ecology of Fish Pest. Doctoral Thesis. Radbound University Nijmegan. Nijmegan. pp. 87-89.

Walker, P. D., J. Russon, R. Duijf., G. V. D. Velde., S. E. W. Bonga. 2011. The Off-Host Survival and Viability of A Native And Non-Native Fish Louse (Argulus, Crustacea: Branchiura). Current Zoology, 57 (6) : 828-835.

Wiegertjes, G. F., and G. Flik. 2004. Host Parasitic Interactions. BIOS Scientific Publishers. USA. pp. 8-9. 